\title{
Influence of soluble haemagglutinins on adherence of Helicobacter pylori to HEp-2 cells
}

\author{
J. A. ARMSTRONG*, MARGARET COOPER, C. S. GOODWINt, JENNIFER ROBINSON, \\ S. H. WEE*, M. BURTON and VALERIE BURKE \\ tDepartment of Microbiology and "Electron Microscopy Unit, Royal Perth Hospital, Perth W.A. 6000, and \\ Gastroenterology and Nutritional Research Unit, Princess Margaret Hospital for Children, Subiaco W.A. 6008, Australia
}

\begin{abstract}
Summary. In a study of six laboratory strains of Helicobacter pylori, two different modes of bacterial adherence to HEp-2 cells were found. Electronmicroscopy revealed that strains known to possess soluble haemagglutinin adhered intimately to the cell surfaces, with cupping of the plasma membrane and coalescence of glycocalyces at sites of attachment. Strains of $\boldsymbol{H}$. pylori without soluble haemagglutinin also attached, but did not induce membrane cupping or show glycocalyx fusion. Light microscopy did not distinguish between these patterns of adherence. Bacterial attachment was unaffected by pre-treatment of HEp2 cells with neuraminidase. Exposure of the bacteria to trypsin or to colloidal bismuth subcitrate (CBS) before being added to HEp-2 cells markedly impaired bacterial adherence. This effect of CBS may contribute to the known efficacy of bismuth therapy in patients with $H$. pylori-related gastritis.
\end{abstract}

\section{Introduction}

Active chronic gastritis and peptic ulcer disease are strongly associated with colonisation of the gastric mucosa by curved or spiral bacteria. ${ }^{1-3}$ These organisms, previously known as Campylobacter pylori, have been re-designated as Helicobacter pylori. ${ }^{4} \mathrm{H}$. pylori displays a preferential affinity for epithelium of the gastric antrum, attaching to mucus-secreting cells through adherence pedestals. ${ }^{2,5-7}$ These attachment sites are similar to those formed by enteropathogenic Escherichia coli on intestinal epithelium. ${ }^{8}$ The ability of bacterial pathogens to adhere to mucosal surfaces and so avoid expulsive mechanisms such as peristalsis, is crucial for colonisation ${ }^{9}$ and it seems likely that adherence of $\boldsymbol{H}$. pylori in the stomach is a pre-requisite for establishment and persistence of infection.

$H$. pylori can adhere to a wide range of cell types in vitro including mouse $\mathrm{Y}-1$ adrenal cells, ${ }^{10}$ human buccal epithelial cells, ${ }^{11}$ HEp-2 and Intestinal 407 cells, ${ }^{12}$ and to HeLa cells. ${ }^{13}$ Presumably there are special factors that effectively restrict its adherence behaviour in vivo; but in-vitro models can be useful for elucidating the modes and mechanisms of interaction between bacterial ligands and surface membrane receptors. ${ }^{14}$ The ability of bacterial ligands to bind with receptors on various species of erythrocytes has led to haemagglutination being employed for the detection of such ligands, or haemagglutinins. It has

Received 18 Dec. 1989 ; revised version accepted 20 Aug. 1990.

†Correspondence should be sent to Professor C. S. Goodwin, Department of Microbiology, Faculty of Medicine and Health Sciences, UAE University, PO Box 15551, Al Ain, United Arab Emirates. identified the ligands as colonisation factors of $E$. coli, ${ }^{15}$ Vibrio cholerae ${ }^{16}$ and Aeromonas spp. ${ }^{17}$ For $H$. pylori there have been varying reports of haemagglutination. Evans et al. ${ }^{18}$ reported that all strains agglutinated strongly all species of erythrocytes tested; but others have described different patterns of haemagglutination with some strains failing to agglutinate any of the erythrocyte species tested. ${ }^{19,20}$

A possible explanation emerged with the finding ${ }^{21}$ that $H$. pylori strains may possess both cell-associated and soluble haemagglutinins, and that the latter is sometimes absent, possibly having been lost in the course of repeated passage. Of two standard passaged strains of $H$. pylori, NCTC 11637 and NCTC 11638, the former regularly produced soluble haemagglutinin whereas the latter did not. An early subculture of NCTC 11638 however, which had been lyophilised 1 month after initial isolation in 1982, had retained the ability to produce soluble haemagglutinin. Other similarly paired and individual strains, with or without soluble haemagglutinins, were identified. ${ }^{21}$

In the present study we have used some of these strains to investigate the influence of soluble haemagglutinin on the adherence of $H$. pylori in vitro, and also the behaviour of the bacterial glycocalyx in this process. ${ }^{4}$ We report also the effects of several treatments that might modify adhesion, including exposure of the organisms to colloidal bismuth subcitrate (CBS).

\section{Materials and methods}

\section{Bacterial strains}

Six strains of $\boldsymbol{H}$. pylori were studied. Four, here designated Q4P, R107P, Q3E and Q3P, were isolated 
from gastric endoscopic biopsy specimens from patients with gastritis at the Royal Perth Hospital. Strains Q4P (NCTC 11637) and R107P have undergone repeated passage in our laboratory, whereas strains Q3E and Q3P comprise, respectively, the 'early' and 'repeatedly-passaged' forms of strain NCTC 11638. Strains designated CP2 and 512 were kindly supplied by Dr Wee Tee (Fairfield Hospital, Melbourne); they too had originated as human gastritis-related isolates and had been passaged repeatedly. Erythrocyte agglutination assay ${ }^{21}$ showed that all six strains possessed cell-associated haemagglutinin. Strains Q4P, R107P and Q3E also produced a soluble haemagglutinin whereas strains Q3P, CP2 and 512 consistently failed to do so. All were preserved by lyophilisation, or at $-70^{\circ} \mathrm{C}$ in peptone water (Oxoid) $1 \% \mathrm{w} / \mathrm{v}$ with glycerol $25 \% \mathrm{v} / \mathrm{v}$. Stock cultures were maintained on solid medium for no longer than 1 month.

\section{Media and reagents}

Cultures were maintained on Brain Heart Infusion Agar (Oxoid), with horse blood lysed with saponin, and incubated in a micro-aerophilic atmosphere containing $\mathrm{CO}_{2} 8 \%, \mathrm{O}_{2} 5 \%, \mathrm{H}_{2} 7 \%$ and $\mathrm{N}_{2} 80 \%{ }^{21}$ Phosphate-buffered saline (PBS) at $\mathrm{pH} \mathrm{7.2} \mathrm{was} \mathrm{used}$ to wash the bacterial suspensions.

\section{Adherence assay}

Bacteria were inoculated on to lysed blood agar and harvested into PBS after 2-3 days to give a concentration equivalent to McFarland standard No. 4-c. (24) $\times 10^{9} \mathrm{cfu} / \mathrm{ml}$. HEp-2 cells, obtained from CSL Laboratories Melbourne, were grown in Earle's Modified Eagles Medium supplemented with fetal bovine serum $10 \% \mathrm{v} / \mathrm{v}$ and glutamine $1 \% \mathrm{w} / \mathrm{v}$ with penicillin $50 \mathrm{IU} / \mathrm{ml}$, neomycin $60 \mathrm{mg} / \mathrm{ml}$ and streptomycin $100 \mathrm{IU} / \mathrm{ml}$, and buffered with sodium bicarbonate solution. Culture plates with 24 wells containing coverslips were inoculated with $1 \mathrm{ml}$ of cell suspension and incubated for $24 \mathrm{~h}$ to obtain semi-confluent monolayers. Monolayers were washed three times with PBS and $1 \mathrm{ml}$ of Eagles Medium added, without antibiotics. Bacterial suspension $(50 \mu \mathrm{l})$ was added to each monolayer and the plates were then incubated at $37^{\circ} \mathrm{C}$ in an atmosphere containing $\mathrm{CO}_{2} 5 \% \mathrm{v} / \mathrm{v}$ for periods of up to $1 \mathrm{~h}$. The monolayers were washed three times with PBS, fixed in methanol $70 \% \mathrm{v} / \mathrm{v}$ for $10 \mathrm{~min}$ and stained with Giemsa stain $10 \% \mathrm{v} / \mathrm{v}$ or by the Warthin-Starry silver impregnation method with Light Green counterstain. ${ }^{22,23}$ Giemsa-stained specimens were mounted in DPX (BDH, Kilsyth, Victoria) and the Warthin-Starry preparations in 'Entellan' (Merck, Darmstadt, Germany) and examined by light microscopy. At least four microscopic fields, comprising at least 200 cells, were assessed, and the numbers of cells with and without visibly adherent bacteria were counted. Results were expressed as the percent- age of cells with attached bacteria and also, where feasible, as the mean number of bacteria/cell. All experiments were performed in duplicate and with parallel controls.

\section{Treatment of bacteria and cells prior to adherence assays}

Trypsin (Sigma) $(1 \mathrm{ml})$ at a concentration of $1 \mathrm{mg} /$ $\mathrm{ml}$ in PBS was added to $0.25 \mathrm{ml}$ of bacterial suspension of strains Q4P, R107P, Q3E and Q3P, which were then incubated at $37^{\circ} \mathrm{C}$ for $30 \mathrm{~min}$. After centrifugation $(10000 \mathrm{~g}$ for $1 \mathrm{~min}$ ) the organisms were washed twice with PBS and resuspended in PBS to a concentration equivalent to McFarland standard No. 4; $50 \mu \mathrm{l}$ of this was added to HEp-2 cell monolayers and the adherence assay was done as described.

Neuraminidase from Clostridium perfringens (Sigma) was prepared in PBS at concentrations of 1 unit and 2 units $/ \mathrm{ml} ; 0.5 \mathrm{ml}$ was added to $\mathrm{HEp}-2$ cell monolayers and incubated at $37^{\circ} \mathrm{C}$ for $10 \mathrm{~min}$. The cells were washed twice with PBS before use with strains Q4P, Q3E and Q3P.

Fetuin and mannose. Fetuin (Sigma) at $2 \mathrm{mg} / \mathrm{ml}$ in PBS, or mannose at $10 \mathrm{mg} / \mathrm{ml}$, were added to an equal volume of the various bacterial suspensions and incubated at room temperature for $20 \mathrm{~min}$.

n-Octylglucose (NOG). Bacteria of strains Q4P, Q3E and Q3P were suspended in $1 \mathrm{ml}$ of NOG (Sigma) $0.5 \% \mathrm{w} / \mathrm{v}$ and incubated for $20 \mathrm{~min}$ at room temperature. Suspensions were then centrifuged at $10000 \mathrm{~g}$ for $1 \mathrm{~min}$ and washed twice with PBS before use.

Mucin. Bacteria of strains Q4P, Q3E and Q3P were suspended in porcine mucin (Sigma) $2 \% \mathrm{w} / \mathrm{v}$ in PBS, and left on ice for $10 \mathrm{~min}$.

Colloidal bismuth subcitrate (CBS) (De-Nol ${ }^{\mathrm{R}}$ : GistBrocades, The Netherlands) was made up in PBS and mixed with suspensions of strains Q4P and Q3P, to give a final concentration of $1 \mathrm{mg} / \mathrm{ml}$. Mixtures were incubated at room temperature for $30 \mathrm{~min}$.

\section{Electronmicroscopy}

Thin sectioning was used to examine the adherence to $\mathrm{HEp}-2$ cells by all six strains of $H$. pylori and also the effects of trypsin, NOG and CBS treatments (of selected strains as above), and neuraminidase pretreatment of the HEp- 2 cell monolayers. The coverslip monolayers were fixed in situ by immersion in glutaraldehyde $2 \cdot 5 \% \mathrm{v} / \mathrm{v}$ in $0 \cdot 16 \mathrm{M}$ cacodylate buffer, $\mathrm{pH} 7 \cdot 2$, for $24 \mathrm{~h}$ at room temperature. After washing with fresh buffer solution the cell sheets were dislodged from the glass with a rubber pusher and incubated, for stabilisation of the glycocalyces, in a solution of tannic acid (Sigma) $1 \% \mathrm{w} / \mathrm{v}$ in $0.16 \mathrm{M}$ cacodylate buffer, pH 7.2, for $24 \mathrm{~h}$ at $4^{\circ} \mathrm{C}$. Subsequent processing comprised post-fixation with aqueous osmium tetroxide $1 \% \mathrm{w} / \mathrm{v}$, dehydration and infiltration with epoxy resin. Duplicate specimens were processed similarly but omitting tannic acid treatment. Thin sections on 
naked copper grids were viewed with a Philips EM 410 (HM) electronmicroscope, after staining with uranyl acetate and lead citrate.

\section{Results}

\section{Adherence to HEp-2 cells as seen by light microscopy}

With all strains of $H$. pylori except strain Q4P, light microscopy of monolayers incubated for $5 \mathrm{~min}$ showed bacteria adhering to only about $10 \%$ (range $5-15 \%$ ) of HEp-2 cells. Strain Q4P exhibited more avid adherence with some $60 \%$ of cells showing attached bacteria. In all monolayers, the intercellular spaces remained virtually free of visible organisms. Adherence levels increased with incubation time. With all strains after $30 \mathrm{~min}, 100 \%$ of HEp- 2 cells had adherent bacteria (fig. 1). The mean number of organisms/cell after 30 min was higher (at almost 50/cell) for strain Q4P than for the other strains. In most monolayers the heaping of abundant organisms over some individual cells made counting difficult. No differences between strains, as to their precise mode of attachment to the cell surfaces, were evident by light microscopy.

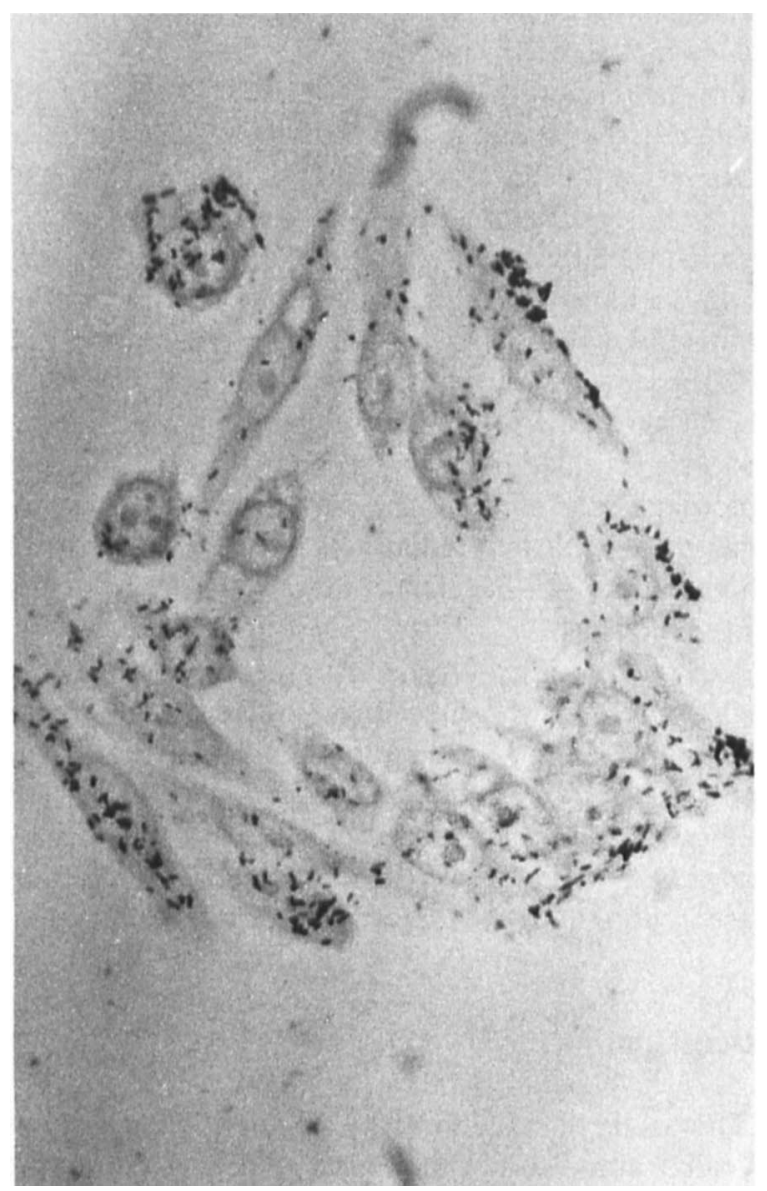

Fig. 1. HEp-2 cell monolayer with adhering $H$. pylori strain Q3P, $30 \mathrm{~min}$ after addition of the bacterial suspension. Warthin-Starry silver stain, $\times 1000$.

\section{Electronmicroscopy}

Electronmicroscopy revealed two different modes of interaction between the bacteria and the HEp-2 cells, which were distinctive and consistently strainrelated. Strains Q4P, R107P and Q3E gave rise to profiles of intimate contact, with shallow cup-like indentations of the cell surface reminiscent of that seen at adherence pedestals in vivo on the gastric mucosa (figs. 2 and 3A). After tannic acid processing for polysaccharide stabilisation, the sites of adherence by these strains of $H$. pylori showed focal blending, or fusion, of the contiguous bacterial and epithelial glycocalyces (fig. 3B). In contrast, strains Q3P, CP2 and 512 failed to develop the same intimacy of adherence; although coming into close apposition with the cell surface (figs. 4 and 5A) they failed to induce the cupping of plasma membranes, or to exhibit coalescence of the glycocalyces despite the bacterial glycocalyx appearing no less well developed than in the other strains (fig. 5B).

\section{Effect of pre-treatment on adherence}

Pre-incubation of the bacteria with trypsin resulted in a marked impairment of adherence by all four of

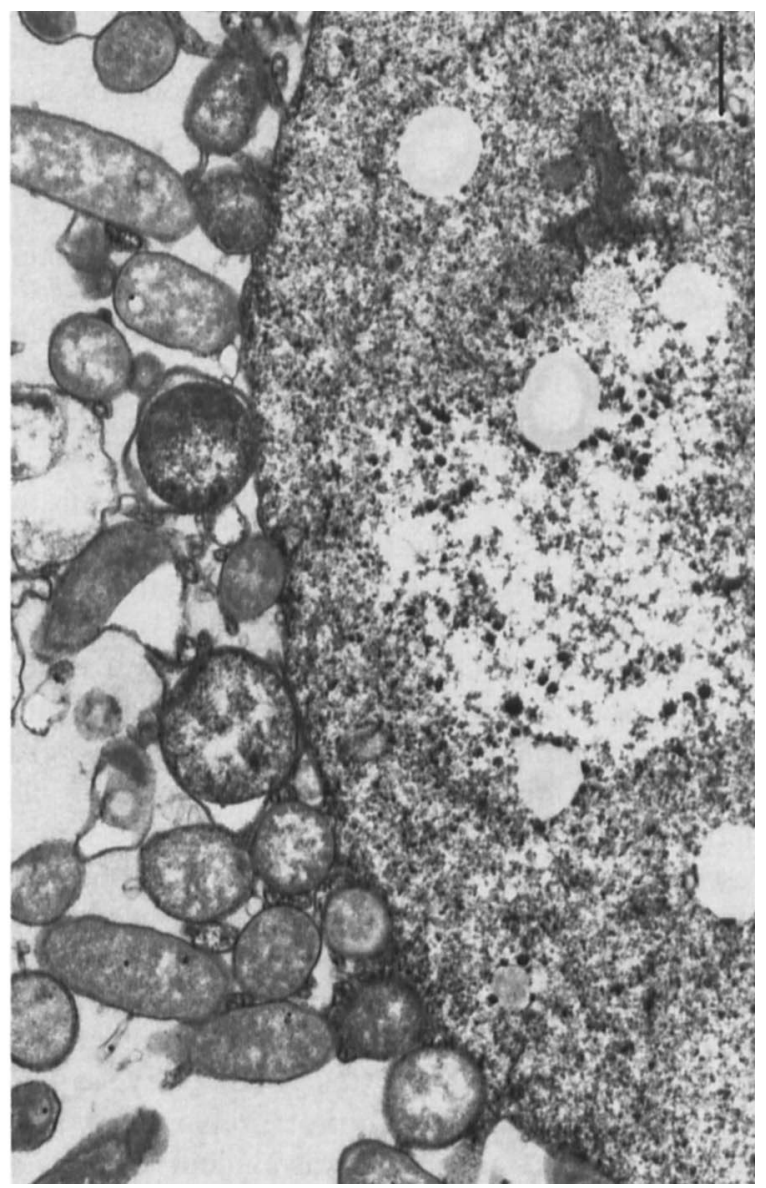

Fig. 2. Electronmicrograph of thin section of HEp-2 cell monolayer inoculated with $\boldsymbol{H}$. pylori strain Q4P and showing organisms heaped and adhering intimately to the cell surface. $B a r=500 \mathrm{~nm}$. 

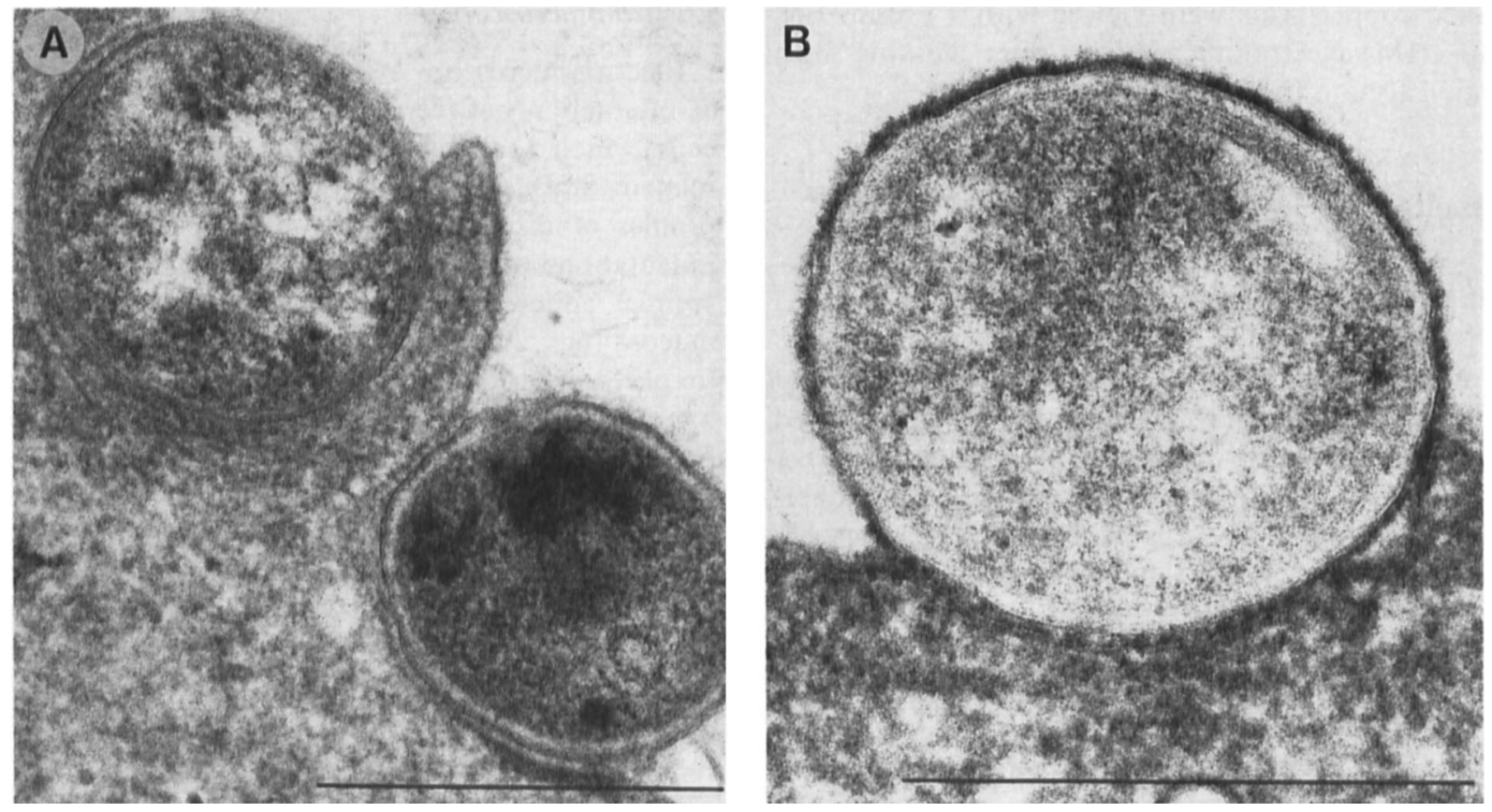

Fig. 3. Electronmicrographs of thin sections showing sites of intimate adherence by $H$. pylori strain Q4P to the HEp-2 cell surface. A shows the appearance after conventional processing, with bacteria embraced in cup-like indentations of the cell membrane. In $\mathbf{B}$, a specimen processed with tannic acid, the glycocalyx appears to be involved in the pedestal-like attachment. Bars $=500 \mathrm{~nm}$.

the $H$. pylori strains tested; $<5 \%$ of HEp-2 cells showed any adherent organisms after $30 \mathrm{~min}$, compared to $100 \%$ in the paired controls. Attached bacteria were too few, in all specimens, for adequate visualisation of attachment by electronmicroscopy of thin sections.

Addition of fetuin or mannose had no detectable influence on adherence behaviour of the various strains; appearances were indistinguishable from their respective controls.

Treatment of $H$. pylori strains Q4P and Q3E with NOG resulted in a marked reduction in the numbers of cells with adhering bacteria. In control preparations, without $\mathrm{NOG}, 100 \%$ of $\mathrm{HEp}-2$ cells showed attached organisms after $30 \mathrm{~min}$. With NOG, <1\% of cells for strain Q3E and $<50 \%$ in the case of strain Q4P had any attached bacteria. Adherence of strain Q3P, in contrast, appeared to be quite unaffected by the preincubation with NOG. Electronmicroscopy of NOGtreated bacteria revealed a severe ultrastructural disruption affecting the interior of the organisms, with a resulting distortion of their shape. However, the microbial cell walls and the glycocalyx were largely preserved and the different modes of adherence between strains Q4P and Q3P were still apparent.

In the presence of porcine gastric mucin, adherence by all strains of $H$. pylori was enhanced. This was not quantifiable in terms of HEp-2 cell numbers with attached organisms as virtually $100 \%$ levels were achieved in the parallel control preparations after incubation for $30 \mathrm{~min}$, but it was evident in terms of mean numbers of bacteria/cell. For example, with addition of mucin the mean number of organisms/cell for strains $\mathrm{Q} 3 \mathrm{E}$ and $\mathrm{Q} 3 \mathrm{P}$ rose to 30 (range 20-50) compared with control values of 15 (range 10-30). For strain Q4P the mean number of organisms adhering increased to $75 /$ cell from a control value on this occasion of $50 /$ cell.

Pre-incubation of strains Q4P and Q3P with CBS resulted in $c$. a 10-fold reduction of bacterial adherence to the HEp-2 cells. For strain Q3P 11\% of cells had adherent organisms after $30 \mathrm{~min}$, with only 3-5 organisms/cell, compared to $100 \%$ of cells and a mean of 45 organisms/cell in the untreated control. For strain Q4P, about $50 \%$ of cells had adherent organisms (5-20 organisms/cell) compared to the control in which all cells showed 50-70 adherent bacteria. Electronmicroscopy revealed no obvious change in the modes of adherence exhibited by the two strains of $H$. pylori apart from a marked reduction in the frequency with which sites of cell-bacteria contact were visualised by thin sectioning.

Exposure of HEp-2 cells to neuraminidase had no visible effect on the subsequent bacterial adherence behaviour of any of the strains tested. In particular, from electronmicroscopy it was evident that the qualitatively distinct modes of adherence shown by strains Q4P and Q3P were not modified by neuraminidase treatment of the target HEp- 2 cells.

\section{Discussion}

This study of six laboratory strains of $H$. pylori has revealed significant differences with regard to the avidity and precise mode of their adherence in vitro to an epithelial cell line. One group of strains, comprising Q4P, R107P and Q3E, regularly showed a propensity 


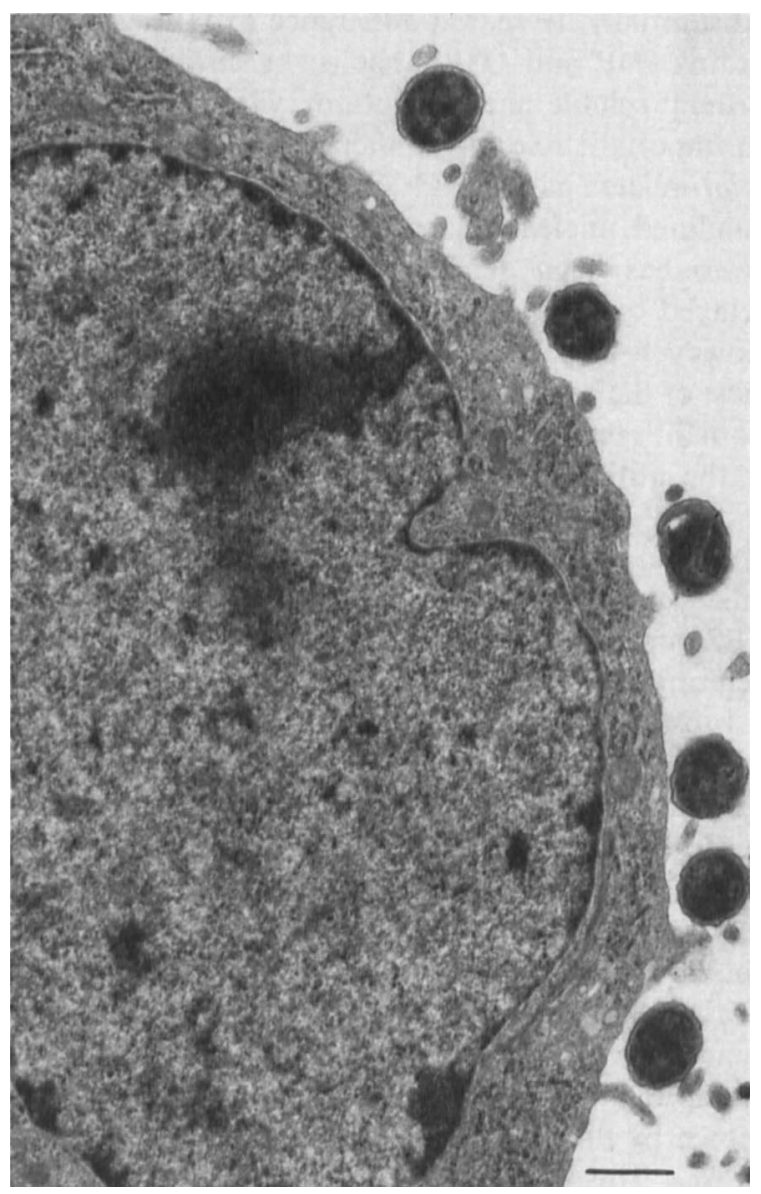

Fig. 4. Electronmicrograph of thin section of a HEp-2 cell monolayer showing close but not intimate adherence of $\boldsymbol{H}$. pylori strain Q3P, $30 \mathrm{~min}$ after addition of the bacterial suspension. $\mathrm{Bar}=500 \mathrm{~nm}$.

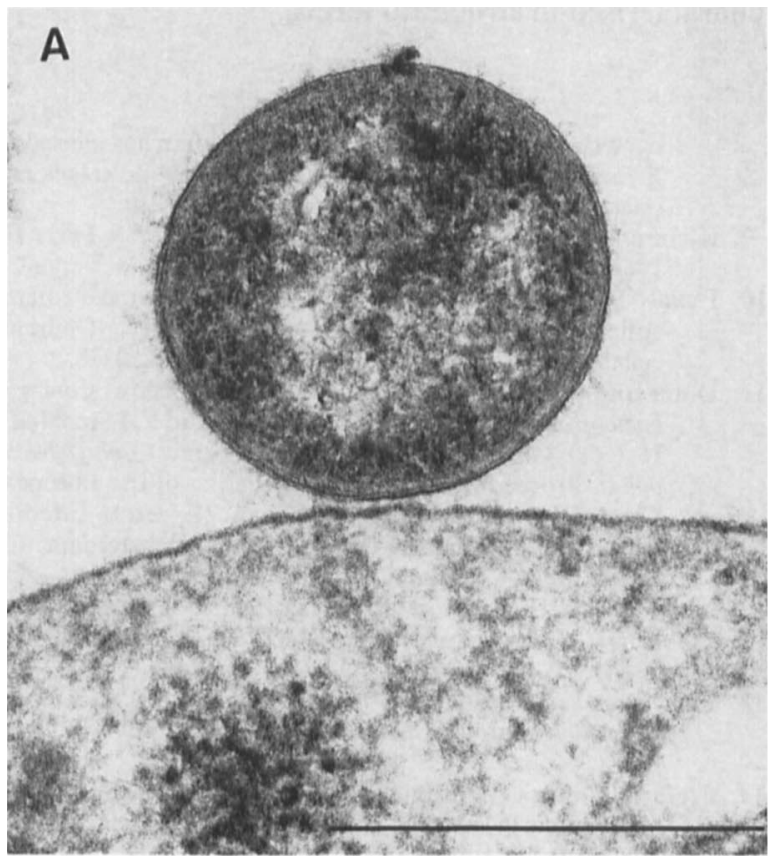

for intimate attachment to the epithelial plasma membrane with coalescence of the glycocalyces, and also cupping profiles as reported in other in-vitro systems. ${ }^{10,12}$ The phenomenon seems analogous to adherence pedestal formation on the gastric mucosa in infected patients. ${ }^{2,5-7,24-26}$

The other strains (Q3P, CP2 and 512) failed to adhere so intimately, lying close to the cell surface but without cupping or glycocalyx fusion. We found the bacterial glycocalyx to be similarly developed in both groups and possession of cell-associated haemagglutinin is also common to both. ${ }^{21}$ However, those strains of $\boldsymbol{H}$. pylori in the first group also produced soluble haemagglutinin whereas the others did not. The findings suggest that this property may indeed promote the intimate mode of adherence. Soluble haemagglutinin production could thus be similarly important in promoting colonisation of gastric epithelium in vivo and be a significant factor in pathogenesis of $H$.pylori infection. At the same time, adherence behaviour of this organism in vivo is clearly selective, and is largely restricted to the gastric mucus-secreting cell type. In vitro, however, it will adhere to a variety of cell lines, ${ }^{11}$ suggesting that additional factors limiting bacterial behaviour in the human stomach may be lacking in cell-culture systems.

The reason why only some strains of $H$. pylori should yield soluble haemagglutinin merits further study and a comparison of strain Q3E (adhering intimately, and a producer of soluble haemagglutinin) with Q3P (failing to adhere intimately, and lacking soluble haemagglutinin) may be significant. This pair of strains consist, respectively, of a salvaged early subculture and a repeatedly-passaged strain of the same original isolate (NCTC 11638). Our findings

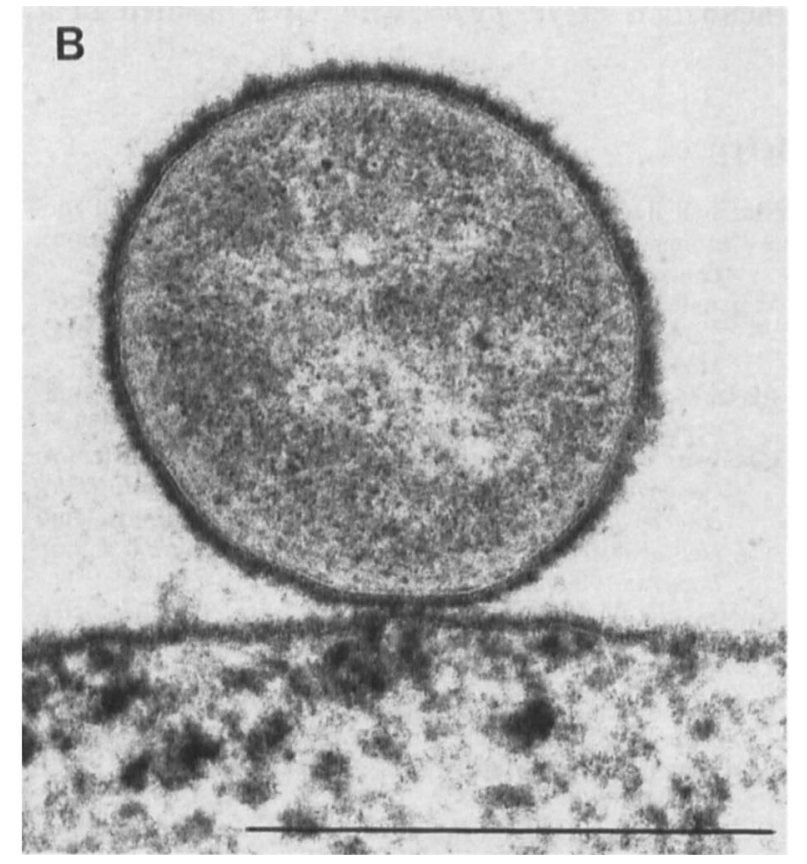

Fig. 5. Electronmicrographs of thin sections showing adherence sites of $H$. pylori strain Q3P, for comparison with fig. 3. A shows the appearance after conventional processing, and $B$, with tannic acid, revealing the bacterial and epithelial glycocalyces. Bars $=500 \mathrm{~nm}$. 
support a previous suggestion that soluble haemagglutinins may have been reduced or entirely lost by some strains during passage. ${ }^{21}$ Nevertheless, the properties of other laboratory strains (e.g., Q4P, identical to NCTC 11637) testify that such loss is by no means an invariable outcome of repeated passage.

Evans et al. ${ }^{18}$ reported that the haemagglutinin of $H$. pylori could be extracted by NOG. Soluble haemagglutinin is also a feature of the strains described by Evans et al. ${ }^{18,21}$ therefore, we attempted in this study to elute the soluble haemagglutinin with NOG to examine the effect on bacterial adherence. By light microscopy, adherence of the strains producing soluble haemagglutinin (Q4P and Q3E) was seen to have decreased, whereas that of a strain not possessing soluble haemagglutinin (Q3P) was unchanged. However, electronmicroscopy revealed that the treatment with NOG caused considerable damage to the internal bacterial structure, although the cell wall appeared to remain intact. Viability of the NOG-treated specimens was markedly affected. Thus, although our findings do suggest different effects of NOG on the two types of strains, the severe morphological damage to the organisms invalidated a comparison related to production of soluble haemagglutinin alone.

We found bacterial adherence to be impaired significantly by treatment with trypsin, suggesting that protein moieties are concerned in the mechanisms of adherence. Addition of fetuin or mannose had no effect, at least as monitored by light microscopy, in agreement with the findings of Leunk et al. ${ }^{27}$ In the presence of porcine gastric mucin there was a modest, but consistent, enhancement of adherence to HEp-2 cells by all the strains of $H$. pylori tested. This apparently reflects the influence of some as yet uncharacterised promoting factor, or factors, present in mucins of gastric origin.

Incubation of $\boldsymbol{H}$. pylori with CBS resulted in a substantially decreased adherence to HEp-2 cells by strains Q4P and Q3P; that is, by strains with and without soluble haemagglutinin. Clinically, CBS has an important role in the therapeutic approach to $H$. pylori-related gastritis ${ }^{3,5,26}$ but its mode of action has remained unclear. Bactericidal activity against $\boldsymbol{H}$. pylori has been demonstrated in vitro, but was of delayed onset with a lag period of several hours. ${ }^{28}$ However, in patients undergoing endoscopic biopsy, most of the colonising bacteria had already dislodged from the mucosa and were degenerating within $90 \mathrm{~min}$ of the initial dosage with CBS. ${ }^{26}$ Interference with bacterial adherence was suggested as a possible mode of action. The present findings are in keeping with this suggestion, but precise mechanisms underlying CBS impairment of $\boldsymbol{H}$. pylori adherence have yet to be determined.

In a previous study, ${ }^{21}$ pre-incubation of erythrocytes with neuraminidase effectively abolished the haemagglutinating activity of soluble haemagglutinin produced by strains Q4P and Q3E, but not that of the cell-associated haemagglutinins. However, we found here that neuraminidase treatment of $\mathrm{HEp}-2$ cells did not significantly influence subsequent adherence by strains Q4P, Q3E or Q3P of $H$. pylori, either quantitatively or (at the ultrastructural level) by modifying the pattern of intimate adherence typically shown by the two soluble haemagglutinin-producing strains. This disparity in the blocking role of neuraminidase suggests that the phenomena may involve different membrane receptors, and supports the view that soluble haemagglutinin of $H$. pylori is polyvalent. ${ }^{21}$ A novel $H$. pylori-binding glyceroglycolipid was recently extracted by Lingwood et al. ${ }^{29}$ from gastric mucosa, human erythrocytes and also HEp-2 cells. It was proposed as the receptor for $H$. pylori common to all three situations, but has yet to be characterised in structural terms.

\section{References}

1. Marshall BJ, Warren JR. Unidentified curved bacilli in the stomach of patients with gastritis and peptic ulceration. Lancet 1984; 1: 1311-1315.

2. Marshall BJ, Royce H, Annear DI et al. Original isolation of Campylobacter pyloridis from human gastric mucosa. Microbios Lett 1984; 25 : 83-88.

3. Blaser MJ. Gastric Campylobacter-like organisms, gastritis, and peptic ulcer disease. Gastroenterology 1987; 93: 371-383.

4. Goodwin CS, Armstrong JA, Chilvers T et al. Transfer of Campylobacter pylori and Campylobacter mustelae to Helicobacter gen. nov. as Helicobacter pylori comb. nov. and Helicobacter mustelae comb. nov., respectively. Int J Syst Bacteriol 1989; 39 : 397-405.

5. Goodwin CS, Armstrong JA, Marshall BJ. Campylobacter pyloridis, gastritis and peptic ulceration. J Clin Pathol 1986; 39: 353-365.

6. Bode G, Malfertheiner P, Ditschuneit H. Pathogenic implications of ultrastructural findings in Campylobacter pylorirelated gastroduodenal disease. Scand J Gastroenterol 1988; 23 Suppl 142: 25-39.

7. Hessey SJ, Spencer J, Wyatt JI et al. Bacterial adhesion and disease activity in Helicobacter associated chronic gastritis. Gut 1990; 31 : 134-138.

8. Cantney JR, Lushbaugh WB, Inman LR. Attachment of

bacteria to intestinal epithelial cells in diarrhea caused by Escherichia coli strain RDEC-1 in the rabbit: stages and role of capsule. J Infect Dis 1981 ; 143: 219-230.

9. Klemm P. Fimbrial adhesins of Escherichia coli. Rev Infect Dis 1985; 7: 321-340.

10. Evans DG, Evans DJ, Graham DY. Receptor-mediated adherence of Campylobacter pylori to mouse Y-1 adrenal cell monolayers. Infect Immun 1989; 57: 2272-2278.

11. Dunn BE, Altmann M, Campbell GP. Adherence of Campylobacter pylori to epithelial cells. In: Mégraud F, Lamouliatte H (eds) Gastroduodenal pathology and Campylobacter pylori. Proceedings of the First Meeting of the European Campylobacter pylori study Group (Excerpta Median International Congress Series vol 847). Amsterdam, Excerpta Medica. 1989: 361-364.

12. Neman-Simha V, Mégraud F. In vitro model for Campylobacter pylori adherence properties. Infect Immun 1988; 56: 33293333.

13. Fauchere JL, Rosenau A, Bonneville F. Virulence factors of Campylobacter pylori. Gastroenterol Clin Biol 1989; 13: B59B64.

14. Freter R, Jones GW. Models for studying the role of bacterial attachment in virulence and pathogenesis. Rev Infect Dis 1983; 5 Suppl 4: S647-S658.

15. Evans DG, Evans DJ, Toja W. Hemagglutination of human group A erythrocytes by enterotoxigenic Escherichia coli 
isolated from adults with diarrhea: correlation with colonization factor. Infect Immun 1977; 18: 330-337.

16. Hanne LF, Finkelstein RA. Characterization and distribution of the haemagglutinins produced by Vibrio cholerae. Infect Immun 1982; 36: 209-214.

17. Burke V, Cooper M, Robinson $\mathrm{J}$ et al. Hemagglutination patterns of Aeromonas spp. in relation to biotype and source. J Clin Microbiol 1984; 19: 39-43.

18. Evans DG, Evans DJ, Moulds JJ, Graham DY. N-acetylneuraminyllactose-binding fibrillar hemagglutinin of Campylobacter pylori: a putative colonization factor antigen. Infect Immun 1988; 56: 2896-2906.

19. Emödy L, Carlsson A, Ljungh $\AA$, Wadström T. Mannoseresistant haemagglutination by Campylobacterpylori. Scand $J$ Infect Dis 1988; 20: 353-354.

20. Huang J, Smyth CJ, Kennedy NP, Arbuthnott JP, Keeling PWN. Haemagglutinating activity of Campylobacter pylori. FEMS Microbiol Lett 1988; 56: 109-112.

21. Robinson J, Goodwin CS, Cooper M, Burke V, Mee BJ. Soluble and cell-associated haemagglutinins of Helicobacter (Campylobacter) pylori. J Med Microbiol 1990; 33: 277-284.

22. Madan E, Kemp J, Westblom TU, Subik M, Sexton S, Cook J. Evaluation of staining methods for identifying Campylobacter pylori. Am J Clin Path 1988; 90 : 450-453.

23. Warthin AS, Starry AC. A more rapid and improved method of demonstrating spirochaetes in tissues. Am J Syph 1920; 4: 97-101.

24. Buck GE, Gourley WK, Lee WK, Subramanyam K, Latimer JM, DiNuzzo AR. Relation of Campylobacter pyloridis to gastritis and peptic ulcer. J Infect Dis 1986; 153: 664-669.

25. Tricottet V, Bruneval $P$, Vire $O$ et al. Campylobacter-like organisms and surface epithelium abnormalities in active, chronic gastritis in humans: an ultrastructural study. Ultrastruct Pathol 1986; 10: 113-122.

26. Marshall BJ, Armstrong JA, Francis GJ, Nokes NT, Wee SH. Antibacterial action of bismuth in relation to Campylobacter pyloridis colonization and gastritis. Digestion 1987; 37 Suppl 2: 16-30.

27. Leunk RD, Ferguson MA, Morgan DR. In vitro adherence and hemagglutination by Campylobacter pylori. In: RuizPalacios GM (ed) Campylobacter V. Proceedings of the fifth international workshop on campylobacter infections, Mexico. 1989: in press.

28. Armstrong JA, Wee SH, Goodwin CS, Wilson DH. Response of Campylobacter pyloridis to antibiotics, bismuth and an acid-reducing agent in-vitro-an ultrastructural study. $J$ Med Microbiol 1987; 24: 343-350.

29. Lingwood CA, Law H, Pellizzari A, Sherman P, Drumm B. Gastric glycerolipid as a receptor for Campylobacter pylori. Lancet 1989; 2: 238-241. 
